\begin{tabular}{cc|c}
\hline Tar. Bil. Der. & Tarım Bilimleri Dergisi & Journal of Agricultural Sciences \\
& $\begin{array}{c}\text { Dergi web sayfası: } \\
\text { www.agri.ankara.edu.tr/dergi }\end{array}$ & Journal homepage: \\
& www.agri.ankara.edu.tr/journal
\end{tabular}

\title{
Morphological and Anatomical Investigations on in Vitro Micrografts of OHxF 333 / Pyrus elaeagrifolia Interstock / Rootstock Combination in Pears
}

\author{
Hatice DUMANOĞLU ${ }^{\mathrm{a}}$, Aysun ÇELIIK ${ }^{\mathrm{a}}$, H. Nurhan BÜYÜKKARTAL ${ }^{\mathrm{b}}$, Saeed DOUSTİ \\ a Ankara University, Faculty of Agriculture, Department of Horticulture, 06110, Ankara, TURKEY \\ ${ }^{b}$ Ankara University, Faculty of Sciences, Department of Biology, 06100, Ankara, TURKEY
}

\section{ARTICAL INFO}

Research Article

DOI: 10.1501/Tarimbil_0000001286

Corresponding Author: Hatice DUMANOĞLU, E-mail: dmanoglu@agri.ankara.edu.tr, Tel: +90 (312) 5961299

Received: 03 December 2013, Received in Revised Form: 02 January 2014, Accepted: 13 January 2014

\begin{abstract}
In this study, possibility of creating a specific interstock / rootstock combination to obtain a clonal, semi dwarf, composite pear rootstock tolerant to various stresses by micrografting was investigated. In vitro shoots of 'Old Home x Farmingdale 333' (Pyrus communis L.) which is a clonal semi dwarf pear rootstock resistant to fireblight and pear decline was used as interstock, and in vitro Pyrus elaeagrifolia Pallas seedlings known as tolerant to Fe-chlorosis, salinity and drought stresses was used as rootstock. Cleft grafting was applied in micrografts. Grafted seedlings were cultured on Murashige and Skoog basal medium with $1 / 2$ strength of macronutrients for 8 weeks under white fluorescent light for $16 \mathrm{~h} \mathrm{day}^{-1}$. Cultures, except the control, received complete darkness either 1 or 2 weeks at the beginning of incubation. Graft take success in the control treatment was significantly higher $(97.9 \%)$ than darkness treatments of 1 or 2 weeks $(90.5 \%$ and $82.5 \%$, respectively). Ultrastructural observations with transmission electron microscope revealed that dividing cambial initials reached to 2-3 layers, and new xylem and phloem elements distinctly differentiated in transverse sections of the graft union 8 weeks after micrografting in the control and darkness treatments. The results indicated a successful graft union formation.

Keywords: Micrografting; Graft union; Interstock; Darkness treatment
\end{abstract}

\section{Armutlarda OHxF 333 / Pyrus elaeagrifolia Ara Anaç / Anaç Kombinasyonunun in vitro Mikroaşılarında Morfolojik ve Anatomik İncelemeler}

\section{ESER BILLGISİ}

Araştırma Makalesi

Sorumlu Yazar: Hatice DUMANOĞLU, E-posta: dmanoglu@agri.ankara.edu.tr, Tel: +90 (312) 5961299

Geliş Tarihi: 03 Aralık 2013, Düzeltmelerin Gelişi: 02 Ocak 2014, Kabul: 13 Ocak 2014 


\section{ÖZET}

Bu çalışmada, mikroaşılama yoluyla çeşitli streslere tolerant, klonal, yarı bodur, birleşik bir armut anacı elde etmek için spesifik bir ara anaç / anaç kombinasyonu oluşturmanın olabilirliği araştırılmıştır. Ateş yanıklığ1 ve armut göçüren hastalıklarına dayanıklı, yarı-bodur armut klon anacı 'Old Home x Farmingdale 333' (Pyrus communis L.)'ün in vitro sürgünleri ara anaç ve demir klorozu, tuzluluk ve kuraklık streslerine tolerant olarak bilinen Pyrus elaeagrifolia Pallas'ın in vitro çöğürleri anaç olarak kullanılmıştır. Mikroaşılarda yarma aşı tekniği uygulanmıştır. Aşılanmış çögürler, makro element düzeyi $1 \frac{1}{2}$ olan Murashige ve Skoog temel besin ortamı üzerinde, 8 hafta süreyle, 16 h gün ${ }^{-1}$ süreyle beyaz floresan 1şık altında inkübe edilmiştir. Kontrol dışındaki kültürler, inkübasyonun başlangıcında, 1 ya da 2 hafta süreyle tamamen karanlık koşullara alınmıştır. Aşı başarısı kontrol uygulamasında (\% 97.9), 1 ya da 2 hafta karanlık uygulamalarından (sırasıyla, \% 90.5 ve \% 82.5) önemli düzeyde daha yüksek olmuştur. Mikroaşılamadan 8 hafta sonra aşı kaynaşma yerinden alınan enine kesitlerde, transmisyon elektron mikroskopu ile yapılan ultrastrüktürel gözlemler, kontrolde ve karanlık uygulamalarında kambiyal inisyallerin bölünerek 2-3 sıraya ulaştığını ve yeni ksilem ve floem elemanlarının belirgin biçimde farklılaştığını ortaya koymuştur. Bulgular başarılı bir aşı kaynaşmasının meydana geldiğini göstermiştir.

Anahtar Kelimeler: Mikroaşılama; Aşı kaynaşması; Ara anaç; Karanlık uygulaması

(C) Ankara Üniversitesi Ziraat Fakültesi

\section{Introduction}

Native Mediterranean Pyrus species P. elaeagrifolia Pallas which has habitat ranging from Turkey to Southeastern Europe and Ukraine (Bell 1990), is a potential pear rootstock in areas where lime, salt and drought are limiting factors for growing many Pyrus species (Lombard \& Westwood 1987; Matsumoto et al 2006). Scions of cultivars (Pyrus communis L.) grafted on $P$. elaeagrifolia grow vigorously similar to pear seedlings causing a long juvenile period. This problem could be overcome by using a dwarf or semi dwarf clonal Pyrus interstocks such as ' $\mathrm{OHxF}$ 333' on P. elaeagrifolia. It is known that interstocks may reduce vegetative growth and enhance reproductive growth of the tree. Such double-worked plants have two unions, one between the rootstock and interstock and one between the interstock and the scion. The interstock piece is budded or grafted or bench grafted onto the rootstock prior to combine with the scion cultivar (Hartmann et al 2011). However, production of grafted-rootstock plants using conventional techniques takes time for at least more than one year considering the growth time of rootstock lines (Elivar \& Dumanoğlu 1999).

In vitro grafting is an original and skillful technique which deserves greater consideration for overcoming the limitations of other vegetative propagation methods, and also for studying more in depth the relationships between genetically different tissues and cells (Monteuuis 2012). In initial studies, the objective of micrografting was elimination of some virus diseases in tree fruit species (Jonard 1986). Murashige et al (1972) and Navarro et al (1975) were first to consider the use of micrografting technique in Citrus species in order to eliminate virus diseases. Micrografting has been successfully applied in Citrus (Edriss \& Burger 1984; Sharma et al 2008), Prunus (Barba et al 1995; Jarausch et al 1999; Conejero et al 2013), Malus (Huang \& Millican 1980; Bisognin et al 2008) and Pyrus (Faggioli et al 1997) species to get plants free from virus or virus like organisms. Besides, micrografting has been used for micropropagation, rejuvenation of mature tissues, determination of graft incompatibility and root to shoot communication, transport or cryopreservation in Citrus (Obeidy \& Smith 1991; Parthasarathy et al 1997; Volk et al 2012), Prunus and Amygdalus (Ozzambak \& Schmidt 1991; Ghorbel et al 1999; Amiri 2006; Y1ldırım et al 2010; Isikalan et al 2011), Malus (Lane et al 2003; Nunes et al 2005; Dobranszki \& Silva 2010), Pyrus (Musacchi et al 2004; Espen et al 2005; Hassanen 2013), Pistacia (Abousalim \& Mantell 1992; Onay et al 2003; 2004; 
Can et al 2006; Ozden-Tokatlı 2010), Castanea and Corylus (Nas \& Read 2003), Actinidia (Ke et al 1993), Olea (Toroncoso et al 1999), Morus (Ma et al 1996), Anacardium (Thimmappaiah et al 2002), Opuntia (Estrada-Luna et al 2002) and Carica (Nava et al 2011) species. Creation of rootstocks by interstock/rootstock combination is possible by in vitro micrografting which is very fast, using in vitro rooted young rootstock plantlets and in vitro grown interstock scions. Thus, micrografting technique offers new possibilities for mass production of grafted rootstocks which might be later grafted in vitro or in vivo with the scion cultivar. Up to date, we are unaware of micrografting studies which have been done for micropropagation of rootstocks grafted with interstock.

The objective of this study was to develop a quick in vitro micrografting technique to create a specific pear rootstock combination using semi dwarf clonal interstock ('Old Home x Farmingdale 333', (OHxF 333)) and the vigorous seedling rootstock tolerant to different stress conditions $(P$. elaeagrifolia), and to study graft union formation on in vitro micrografted and complate darkness treated plantlets, since complete darkness may prevent internal auxin degradation, by morphological and anatomical (Transmission Electron Microscope) investigations.

\section{Material and Methods}

\subsection{Rootstock and scion (interstock) sources for micrografting experiments}

In vitro germinated seedlings of $P$. elaeagrifolia Pallas were used as the rootstock. The seeds were processed before culturing in aseptic conditions as follows; (1) the seeds were scarified in sulfuric acid (Merck, 95-98\% $\mathrm{H}_{2} \mathrm{SO}_{4}$ ) for 2.5 min followed by rinsing in running water for $5 \mathrm{~min}$, (2) the seeds were dipped in $85 \%$ ethanol for $3 \mathrm{~min}$, and then sterilized in a solution of sodium hypochlorite (2.5\% active chlorine) for $30 \mathrm{~min}$ followed by 3 rinses for $5 \mathrm{~min}$ with sterile distilled water. Then, the seeds were placed on germination medium in petri dishes by positioning vertically so that the radical of the seed was in the medium. Five seeds were placed in each petri dish $(70 \times 10 \mathrm{~mm})$. The seeds were stratified in vitro at $4{ }^{\circ} \mathrm{C}$ in dark for 8 weeks in order to break dormancy. Chilled seeds were germinated in a growth chamber at $25 \pm 1$ ${ }^{\circ} \mathrm{C}$ under 16/8 h day ${ }^{-1}$ (light/dark) photoperiod

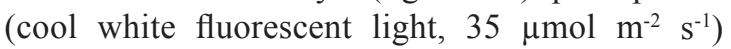
for 10-14 days. MS basal medium (Murashige \& Skoog 1962) with half-strength of macronutrients, containing 3\% $\left(\mathrm{w} \mathrm{v}^{-1}\right)$ sucrose and $1 \%\left(\mathrm{w} \mathrm{v}^{-1}\right)$ Difco Bacto agar was used in seed stratification and germination studies. The $\mathrm{pH}$ was adjusted to 5.8 before adding agar and autoclaving at $121{ }^{\circ} \mathrm{C}$ for $20 \mathrm{~min}$.

In vitro shoots obtained from shoot-tip culture of 'OHxF 333' were used as scion (interstock). Shoot-tip cultures were established from actively growing shoots of plants. Shoot tips approximately $20 \mathrm{~mm}$ long were collected, washed in running tap water for $30 \mathrm{~min}$, and sterilized by immersion in a solution of sodium hypochlorite $(1 \%$ active chlorine) for $20 \mathrm{~min}$ followed by 3 rinses with sterile distilled water for $5 \mathrm{~min}$. Approximately $10 \mathrm{~mm}$ long explants were cultured in glass tubes $(120 \times 25 \mathrm{~mm})$ containing $10 \mathrm{~mL}$ of medium under aseptic conditions. The shoots ( $\geq 10 \mathrm{~mm}$ long) from initial cultures were subcultured four times by four week intervals in glass flasks $(250 \mathrm{~mL})$ containing $50 \mathrm{~mL}$ of medium.

For initial culture and subcultures, MS basal medium containing $3 \%\left(\mathrm{w} \mathrm{v}^{-1}\right)$ sucrose and $0.7 \%(\mathrm{w}$ $\left.\mathrm{v}^{-1}\right)$ agar was used. MS medium was supplemented with $4.4 \mu \mathrm{M}$ BA and $0.9 \mu \mathrm{M} \mathrm{GA}_{3}$ which were were added to media before autoclaving at $121^{\circ} \mathrm{C}$ for 20 $\min$. The $\mathrm{pH}$ was adjusted to 5.8 before adding agar. All cultures were incubated at the same conditions as seed germination.

\subsection{In vitro micrografting experiments}

Cleft grafting was applied in micrografts under aseptic conditions. About 10-14 day-old seedlings with horizontal cotyledonary leaves, without true leaves, with roots about $15-30 \mathrm{~mm}$ in length were used as rootsock in grafts (Figure 1A). 

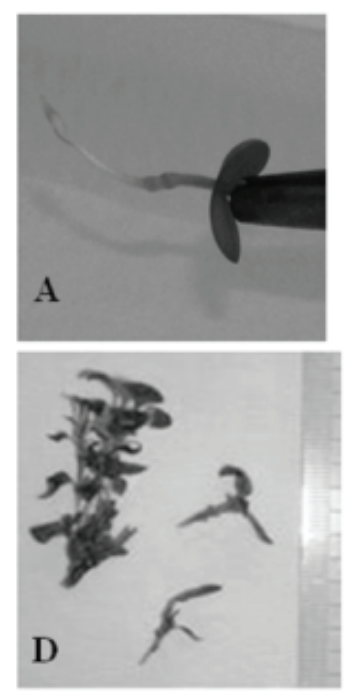
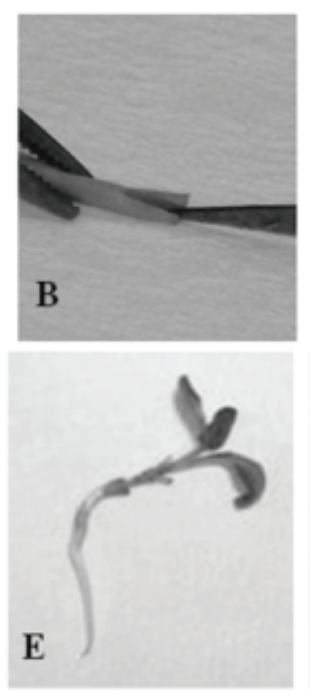
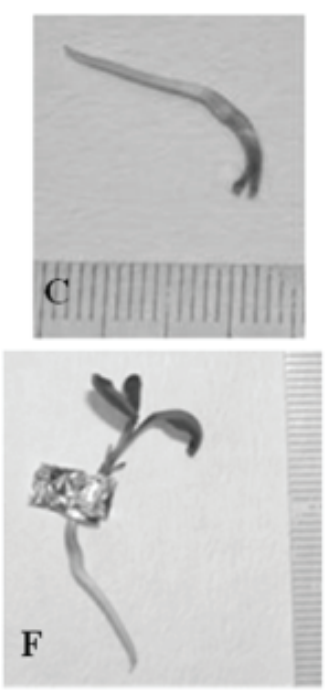

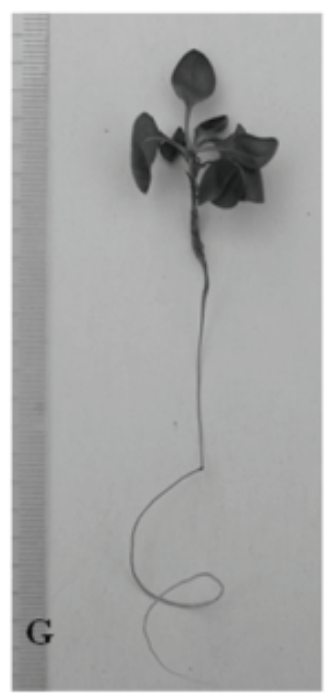

Figure 1- Micrografting procedure of interstock 'OHxF 333' on Pyrus elaeagrifolia seedling under aseptic conditions. An in vitro germinated $P$. elaeagrifolia seedling (A); forming a cleft at about $2-3 \mathrm{~mm}$ in length on the top of hypocotyle of seedling which was cut just below the cotyledon leaves (B); an in vitro grown seedling ready for micrografting (C); a scion prepared from an in vitro grown interstock ' $O H x F$ 333' micro shoots ready to be inserted into the cleft (D); an inserted scion into the cleft (E); a graft union wrapped around with sterile aluminum foil (F); a micrografted plantlet taken out from in vitro conditions after 8 weeks of grafting (G)

Şekil 1- Pyrus elaeagrifolia çögürleri üzerine 'OHxF 333' ara anacının, aseptik koşullarda mikroaşılama işlemi. In vitro koşullarda çimlendirilmiş P. elaeagrifolia çögürleri (A); kotiledon yaprakların hemen altından tepesi vurulmuş fidelerin hipokotilinin üst kısmında yaklaşı 2-3 mm uzunluğunda bir yarık oluşturulması (B); mikroaşılama için hazır bir in vitro çögüü (C); in vitro koşullarda geliştirilmiş ara anaç 'OHxF 333'den kalem olarak hazırlanmış, yarık içerisine yerleştirilmeye hazır mikro sürgünler (D); yarık içerisine kalemin yerleştirilmesi (E); aşı yerinin steril alüminyum folyo ile sarılması (F); aşılamadan 8 hafta sonra in vitro koşullardan çılkartılmış bir mikroaşılı bitkicik $(G)$

The roots were cut to $\sim 20 \mathrm{~mm}$ length. The tip of hypocotyl was decapitated just below the cotyledons. The stem was cut longitudinally $2-3 \mathrm{~mm}$ deep (Figure 1B \& C). The scion, prepared from in vitro shoots of 'OHxF 333' was about $10 \mathrm{~mm}$ long and contained the apical meristem with 2-3 leaves. The basal end of the scion was cut to form a wedge about 2-3 mm long (Figure 1D). The scion was inserted into the cleft and the graft junction was wrapped with a sterile $5 \times 20 \mathrm{~mm}$ piece of aluminum foil (12 $\mu$ thick) which was folded 4 times (Figure 1E \& F). The basal end of grafted seedlings was placed in the medium with the graft junction above the level of medium in glass tubes $(120 \times 25 \mathrm{~mm})$ containing $10 \mathrm{~mL}$ of half-strength MS basal medium without growth regulators containing $3 \%\left(\mathrm{w} \mathrm{v}^{-1}\right)$ sucrose and $0.7 \%\left(\mathrm{w} \mathrm{v}^{-1}\right)$ agar. The $\mathrm{pH}$ was adjusted to 5.8 before adding agar and autoclaving.

For the micrografting experiments, grafted seedlings received either complete darkness for 1 or 2 weeks in a growth chamber or $16 / 8 \mathrm{~h} \mathrm{day}^{-1}$ (light / night) photoperiod (control) at $25 \pm 1{ }^{\circ} \mathrm{C}$. At the end of the dark treatments, cultures were incubated under the photoperiod as the control received. The micrografting experiments were a completely randomized design with four replications with 
25 micrografts (tubes) in each replication. The experiment was repeated at least twice to ensure the accuracy of results.

\subsection{Morphological investigations of micrografted plantlets}

Grafted plantlets were removed from in vitro conditions 8 weeks after micrografting and the aluminum band was removed (Figure $1 G$ ). Percent graft take, graft junction rating on a scale of 1 to $3(1$ = weak, $2=$ medium, $3=$ good) by visual inspection, shoot length and number of leaves on the shoots were recorded. Morphological data were subjected to analyses of variance (ANOVA) at $P \leq 0.05,0.01$ or 0.001 using MINITAB statistical software (MINITAB Inc., UK). Means were separated by Duncan's multiple range test at $P=0.05$. The percent data were transformed into angle values prior to analyses.

\subsection{Preparation of epon blocks and anatomic investigations}

Tissue samples in size of $2 \mathrm{~mm}$ lenght were taken from the graft union 8 weeks after the micrografts were made. The samples were fixed in $3 \%$ glutaraldehyde buffered with $0.1 \mathrm{M}$ phosphate $(\mathrm{pH}$ 7.2) for $3 \mathrm{~h}$ and then fixed in $1 \%$ osmium tetraoxide (in $0.1 \mathrm{M}$ Na-P buffer) for $3 \mathrm{~h}$ at room temperature. Specimens were dehydrated in an ethanol series, transferred to $100 \%$ propylene oxide and embedded in Epon 812 (Luft 1961). Ten blocks were prepared for each treatment. Ultrathin sections were stained with uranyl acetate (Stempak \& Ward 1964) and lead citrate (Sato 1967). Ultrastructural observations were made under Jeol CXII Transmission Electron Microscope at $80 \mathrm{Kv}$.

\section{Results and Discussion}

In this study, very high graft take success was obtained in the micrografts of ' $\mathrm{OHxF} 333$ ' / P. elaeagrifolia seedlings. Based on morphological observations, the highest graft take and graft junction rating was $97.9 \%$ and $2.70 \%$, respectively (Table 1 ).

Hassanen(2013) found that the highestpercentage of successful grafts was $83 \%$ in the Le-Cont pear / Pyrus betulaefolia combination. Nunes et al (2005) reported that in vitro micrografting techniques offer the potential for effective propagation of high quality genetic material in a short time under controlled and aseptic conditions. Grafting techniques and initial treatments applied prior to in vitro micrograftings are subjects of concern. Cleft grafting was used in this study because it has been reported as a successful micrografting technique in different fruit species such as cherry, pistachio, olive (Ozzambak \& Schmidt 1991; Abousalim \& Mantell 1992; Toroncoso et al 1999; Onay et al 2004).

Table 1- The effect of complete darkness treatments applied at the beginning of incubation, on graft take success and shoot development in 'OHxF 333' / Pyrus elaeagrifolia seedling interstock/ rootstock combinations in vitro (after 8 weeks of micro-cleft graftings)

Çizelge 1- In vitro koşullarda inkübasyon başlangıcında uygulanan tamamen karanlık uygulamalarının 'OHxF 333’ / Pyrus elaeagrifolia çöğ̈ürü ara anaç / anaç kombinasyonunda aşı başarısı ve sürgün gelişimi üzerine etkileri (mikro-yarma aşılamadan 8 hafta sonra)

\begin{tabular}{|c|c|c|c|c|}
\hline Treatments & $\begin{array}{c}\text { Graft take } \\
(\%)\end{array}$ & $\begin{array}{c}\text { Graft junction rating } \\
(1-3)\end{array}$ & $\begin{array}{l}\text { Shoot length } \\
(\mathrm{mm})\end{array}$ & $\begin{array}{l}\text { Number of } \\
\text { leaves }\end{array}$ \\
\hline Control & $97.9 \mathrm{a}$ & $2.70 \pm 0.06 \mathrm{a}$ & $13.9 \pm 0.8 \mathrm{a}$ & $6.8 \pm 0.5 \mathrm{a}$ \\
\hline Complete darkness for a week & $90.5 b$ & $2.33 \pm 0.13 b$ & $10.6 \pm 0.4 b$ & $3.9 \pm 0.0 \mathrm{~b}$ \\
\hline Complete darkness for two weeks & $82.5 b$ & $2.09 \pm 0.13 b$ & $10.9 \pm 0.6 b$ & $4.5 \pm 0.3 b$ \\
\hline$P$ & 0.001 & 0.011 & 0.011 & 0.000 \\
\hline
\end{tabular}

Graft junction rating 1, weak; 2, medium; 3, good. Means in each column followed by the same letter were not significantly different at $P=0.05$, according to Duncan's new multiple range test 
We applied complete dark treatment for 1 or 2 weeks as an initial procedure with an expectation of increasing graft take success by promoting callus formation due to its role in internal auxin biosynthesis (Yin et al 2012). Endogenous growth regulators have been proposed to play a key role in grafting, with special reference to auxin which is known to be synthesized in shoot apices and degraded by light. Our results showed that although graft take success, graft junction rating, leaf number and shoot development were satisfactory in all treatments, the control treatment performed significantly better than the dark treatments (Table 1). The control treatment had the highest graft take among the treatments $(P=0.001)$ which was followed by 1 week $(90.5 \%)$ and 2 weeks $(82.5 \%)$ darkness treatments although the difference between last two was not statistically significant. The grade for level of graft junction was also high on grafts and the differences were significant. The control treatment had the highest grade $(2.70 \pm 0.06)$ followed by 1 week $(2.33 \pm$ $0.13)$ and 2 weeks of complete darkness (2.09 \pm 0.13 ) treatments. (Table 1). The results are in agreement with the report of Monteuuis (1996) that the application of dark treatment for 2 weeks in in vitro micrografts did not improve the results in Acacia mangium. On the other hand, Monteuuis (1994) observed beneficial effects of 2 weeks to 3 weeks in darkness immediately after grafting in vitro seedlings of Picea abies which resulted in $52.4 \%$ success as compared to $32.6 \%$ for the control. Similarly, 5 days of dark treatment shortened the time required for grafting and increased the graft union rate $(90.6 \%)$ compared with the control $(80.7 \%)$ in the plug seedling of rose rootstock (Han et al 1998).

Ultrastructural observations with transmission electron microscope in ' $\mathrm{OHxF} 333$ ' / P. elaeagrifolia micrografts revealed the successful graft union formation, and new xylem and phloem elements differentiated in all of the treatments. In the control, observation of callus tissue between graft elements at the graft union revealed that the cells at the graft union were generally oval in shape and scattered (Figure 2A).
Transverse sections of a region near graft elements showed that parenchymatous cells forming callus tissue were large and had larger intercellular spaces. In some of these cells the cytoplasm was less dense and contained vacuoles and a few organelles (Figure 2B). Some enlarged cells and occasionally divided cambial initials were observed at the graft union. Cambial cells were formed by couple of cell layers (Figure 2C), and cytoplasm of some of the cells were dense (Figure 2D). Xylem elements and phloem cells were formed by couple of cell layers and they were starting to differentiate. Tracheal elements which were in the process of differentiation had reached their normal size and the lumen of the cell was dense with electrons (Figure 2E). Phloem cells were found to be round, isodiametric or hexagonal in shape, thin walled and dispersed.

In one week complete darkness treatment, parenchymatous cells with rough walls forming the callus tissue between the graft elements were plenty and the cytoplasm stained dark (Figure 3A). At this stage, the cambial relation was present between graft elements. Cambium cells were formed with cells of different sizes and occasionally formed 7 or 8 layers. These cells had thin walls, were rectangular in shape, and formed radial rows. The cytoplasm stained very dark in some cells. There were few newly formed xylem and phloem elements (Figure 3B).

In two weeks of complete darkness treatment, callus tissue between the graft elements at the graft union was dense in samples treated. The cells at the union tissues were generally flattened and dispersed. However, parenchymatous cells producing the callus tissue were formed by large cells with large inter-cellular spaces. The cytoplasm in some cells was dense. Cambium was formed of couple of cell rows and the cytoplasm in some cells was dense. At this stage, the established cambial relation between graft elements was very clear. New xylem and phloem elements were few in number and they started to differentiate (Figure 4).

Espen et al (2005) indicated that the incompatible heterograft (Pyrus communis L. cv. 'Bosc' (B) / 

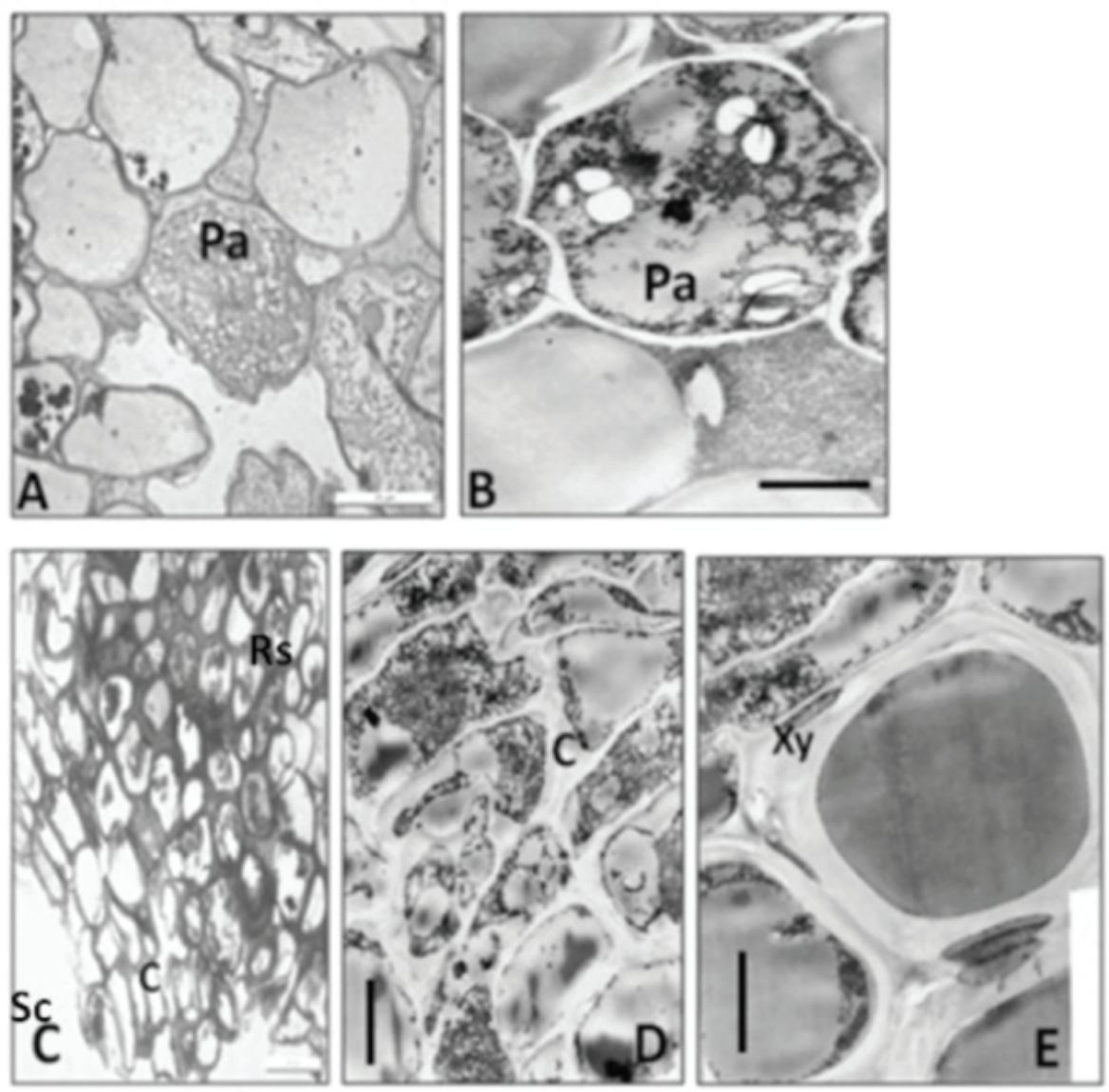

Figure 2- Transversal sections of the graft union in the control treatment after 8 weeks of micrografts. Rs, rootstock (P. elaeagrifolia seedling); Sc, scion (OHxF 333 interstock); Xy, xylem; C, cambium; Pa, parenchymatous cell. Semithin section showing parenchymatous cells at the graft union Bar $=20 \mu \mathrm{m}$ (A); electron micrograph showing detail of parenchymatous cell cytoplasm Bar $=3 \mu \mathrm{m}(B)$; semithin section showing cambial cells and newly differentiated xylem and phloem cells Bar $=50 \mu \mathrm{m}(\mathrm{C})$; the cytoplasm of the active cambial cells Bar $=\mathbf{3} \boldsymbol{\mu m}$ (D); detail of the newly differentiated xylem cells Bar $=\mathbf{3} \boldsymbol{\mu m}(\mathrm{E})$

Şekil 2- Mikroaşılamadan 8 hafta sonra kontrol uygulamasında aşı kaynaşma yerinden alınan enine kesitler. $R s$, anaç (P. elaeagrifolia çögürü); Sc, ara anaç (OHxF 333); Xy, ksilem; C, kambiyum; Pa, parankimatik hücre. Aşı kaynaşma yerinde parankimatik hücreleri gösteren yarl ince kesit Bar= $20 \mu \mathrm{m}$ (A); parankimatik hücre sitoplazmasının ince yapısın gösteren elektron mikrografisi Bar $=3 \mu \mathrm{m}(B)$; kambiyum hücreleri ve yeni farklılaşmış ksilem ve floem hücrelerini gösteren yarince kesit Bar=50 $\mu \mathrm{m}(C)$; aktif kambiyum hücrelerinin sitoplazması Bar= $3 \mu \mathrm{m}(D) ;$ yeni farklılaşmış ksilem hücrelerinin ince yapısı Bar= $3 \mu \mathrm{m}(E)$

Cydonia oblonga Mill. East Malling clone C (EMC)) showed a marked delay in internode cohesion compared with the autografts of $\mathrm{B} / \mathrm{B}$, and Pyrus communis L. cv. 'Butirra Hardy' (BH/
$\mathrm{BH})$ and the compatible heterograft (BH / EMC). Thus we believe that, 'OHxF 333' / P. elaeagrifolia combination would form a compatible heterograft. 

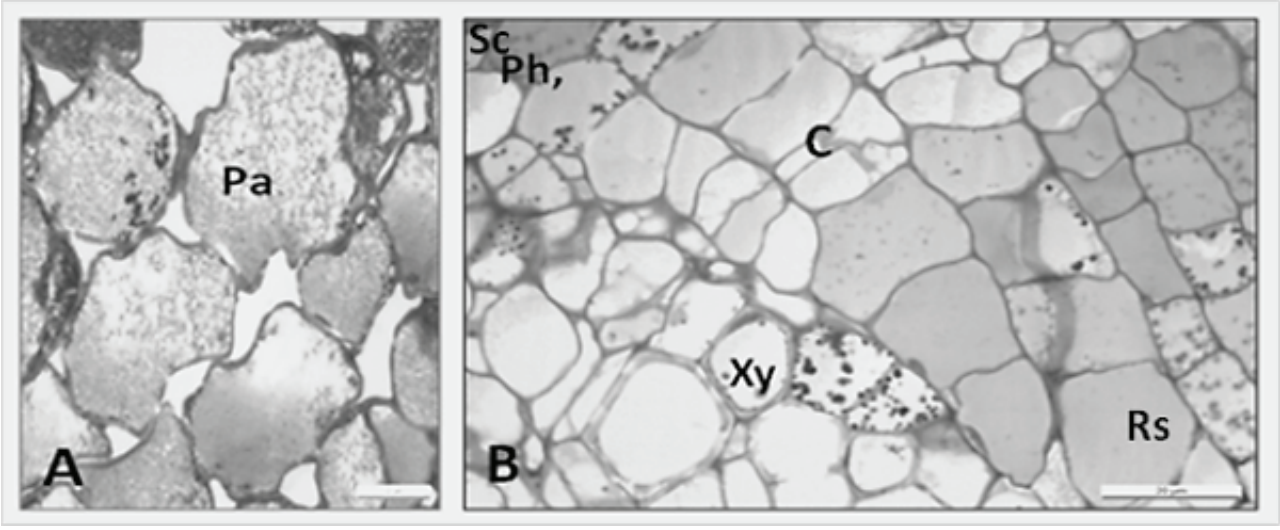

Figure 3- Transversal semithin sections of the graft union in 1 week complete darkness treatment after 8 weeks of micrografts. Rs, rootstock (P. elaeagrifolia seedling); Sc, scion (OHxF 333 interstock); Xy, xylem; Ph, phloem; C, cambium; Pa, parenchymatous cell. Parenchymatous cells at the graft union Bar $=20 \mu \mathrm{m}$ (A), cambial cells, newly differentiated xylem and phloem cells Bar $=20 \mu \mathrm{m}$ (B)

Şekil 3-Mikroaşılamadan 8 hafta sonra 1 hafta tamamen karanlı uygulamasında aşı kaynaşma yerinden alınan enine kesitler. Rs, anaç (P. elaeagrifolia çögüüü); Sc, ara anaç (OHxF 333); Xy, ksilem; Ph, floem; C, kambiyum; Pa, parankimatik hücre. Aşı kaynaşma yerinde parankimatik hücreler Bar $=20 \mu \mathrm{m}$ (A), kambiyum hücreleri, yeni farklılaşmış ksilem ve floem hücreleri Bar $=20 \mu m(B)$

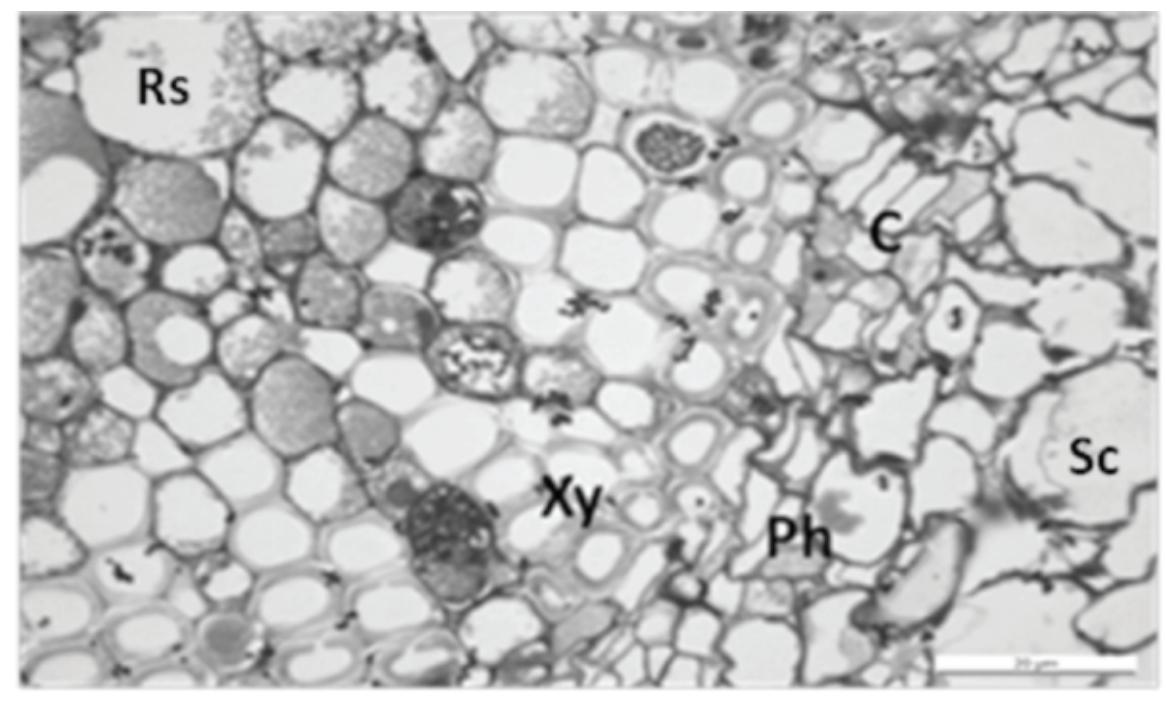

Figure 4- Transversal sections of the graft union in 2 weeks complete darkness treatment after 8 weeks of micrografts. Cambial ring and newly differentiated xylem and phloem cells Bar $=20 \mu \mathrm{m}$ Rs, rootstock $(P$. elaeagrifolia seedling); Sc, scion (OHxF 333 interstock); Xy, xylem; Ph, phloem; C, cambium

Şekil 4- Mikroaşılamadan 8 hafta sonra 2 hafta tamamen karanlık uygulamasında aşı kaynaşma yerinden alınan enine kesitler. Kambiyum halkası ve yeni farklılaşmış ksilem ve floem hücreleri Bar $=20 \mu m$ Rs, anaç ( $P$. elaeagrifolia çögürü); Sc, ara anaç (OHxF 333); Xy, ksilem; Ph, floem; C, kambiyum 


\section{Conclusions}

In vitro micrografting technique was successfully applied to create 'OHxF 333' / P. elaeagrifolia seedling combination. Thus, with mass micropropagation it is possible to shorten the required time for production of a pear rootstock consisted of rootstock and interstock which is clonal, semi dwarf, tolerant to Fe-chlorosis, salinity and drought stresses, and resistant to fireblight and pear decline less than a year. This is the first report of in vitro micrografting on Pyrus elaeagrifolia Pallas wild pear, and micropropagation of rootstock plants which are micrografted with interstock in vitro.

\begin{tabular}{|ll|}
\hline \multicolumn{2}{|c|}{ Abbreviations and Symbols } \\
\hline $\mathrm{C}$ & cambium \\
$\mathrm{MS}$ & murashige \& skoog \\
$\mathrm{Pa}$ & parenchymatous \\
$\mathrm{Ph}$ & phloem \\
$\mathrm{Rs}$ & rootstock (P. elaeagrifolia seedling) \\
$\mathrm{Sc}$ & scion (OHxF 333 interstock) \\
$\mathrm{Xy}$ & xylem \\
\hline
\end{tabular}

\section{References}

Abousalim A \& Mantell S H (1992). Micrografting of pistachio (Pistacia vera L. cv. Mateur). Plant Cell, Tissue and Organ Culture 29: 231-234

Amiri M A (2006). In vitro techniques to study the shoot-tip grafting of Prunus avium L. (cherry) var. Seeyahe Mashad. Journal of Food Agriculture and Environment 4: 151-154

Barba M, Cupidi A, Loreti S, Faggioli F \& Martino $\mathrm{L}$ (1995). In vitro micrografting: a technique to eliminate peach latent mosaic viroid from peach. Acta Horticulturae 386: 531-535

Bell R L (1990). Pears (Pyrus). In: Moore J N \& Ballington J R (Eds), Genetic Resources of Temperate Fruit and Nut Crops, International Society for Horticultural Science, Wageningen, pp. 655-696

Bisognin C, Ciccotti A, Salvadori A, Moser M, Grando M S \& Jarausch W (2008). In vitro screening for resistance to apple proliferation in Malus species. Plant Pathology 57: 1163-1171

Can C, Ozaslan M, Toremen H, Sarpkaya K \& Iskender E (2006). In vitro micrografting of pistachio, Pistacia vera L. var. Siirt, on wild pistachio rootstocks. Journal of Molecular Cell Biology 5: 25-31

Conejero A, Romero C, Cunill M, Mestre M A, MartínezCalvo J, Badenes M L \& Llácer G (2013). In vitro shoot-tip grafting for safe Prunus budwood exchange. Scientia Horticulturae 150: 365-370

Dobranszki J \& Silva J A T (2010). Micropropagation of apple - A review. Biotechnology Advances 28: 462488

Edriss M H \& Burger D W (1984). Micro-grafting shoottip culture of Citrus on three trifoliolate rootstocks. Scientia Horticulturae 23: 255-259

Elivar D E \& Dumanoğlu H (1999). Ayaş (Ankara) koşullarında elma, armut ve ayvada bir yaşlı fidan üretiminde ilkbahar sürgün ve sonbahar durgun göz aşılarının karşılaştırılması. Tarım Bilimleri Dergisi 5(2): 58-64

Espen L, Cocucci M \& Sacchi G A (2005). Differentiation and functional connection of vascular elements in compatible and incompatible pear / quince internode micrografts. Tree Physiology 25: 1419-1425

Estrada-Luna A A, Lopez-Peralta C \& Cardenas-Soriano $\mathrm{E}$ (2002). In vitro micrografting and the histology of graft union formation of selected species of pricly pear cactus (Opuntia spp.). Scientia Horticulturae 92: 317-327

Faggioli F, Martino L \& Barba M (1997). In vitro micrografting of Pyrus communis shoot tips. Advances in Horticultural Science 11: 25-29

Ghorbel A, Chatibi A, Thaminy, S \& Kchouk M L (1999). Micrografting of almond Prunus dulcis (Miller) D.A. Webb.) cv. Achak. Acta Horticulturae 470: 429-433

Han Y Y, Woo J H, Sim Y G, Choi K B, Choi B S \& Yeo S K (1998). Studies on the plug seedling of rose rootstock (Rosa multiflora 'Hort No. 1'). RDA Journal of Horticulture Science 40: 82-88

Hartmann H T, Kester D E, Davies F T \& Geneve R L (2011). Plant Propagation: Principle and Practices. Prentice-Hall, London

Hassanen S A (2013). In vitro grafting of pear (Pyrus spp.). World Applied Sciences Journal 21: 705-709

Huang S C \& Millican D F (1980). In vitro micrografting of apple shoot tips. HortScience 15: 741-743

Isıkalan C, Namli S, Akbas F \& Ak B E (2011). Micrografting of almond (Amygdalus communis) cultivar 'Nonpareil'. Australian Journal of Crop Science 5: 61-65 
Jarausch W, Lansac M, Bliot C \& Dosbat F (1999). Phytoplasma transmission by in vitro graft inoculation as a basis for a preliminary screening method for resistance in fruit trees. Plant Pathology 48: 283-287

Jonard R (1986). Micrografting and its applications to tree improvement. In: Bajaj Y P S (Ed). Biotechnology in Agriculture and Forestry, Springer, Berlin, pp. 31-48

Ke S, Cai Q \& Skirvin R M (1993). Micrografting speeds growth and fruiting of protoplast-derived clones of kiwifruit (Actinidia deliciosa). Journal of Horticultural Science 68: 837-840

Lane W D, Bhagwat B, Armstrong J D \& Wahlgren S (2003). Apple micrografting protocol to establish transgenic clones on field ready rootstock. HortTechnology 13: 641-646

Lombard P B \& Westwood M N (1987). Pear rootstocks. In: Rom R C \& Carlson R F (Eds). Rootstocks for Fruit Crops, A Wiley-Interscience Publication, John Wiley and Sons, Inc., New York, pp. 145-183

Luft J H (1961). Improvements in epoxyresin embedding methods. The Journal of Biophysical and Biochemical Cytology 9: 409-414

Ma F, Guo C, Liu Y, Li M, Ma T, Mei L \& Hsiao A (1996). In vitro shoot-apex grafting of mulberry (Morus alba L.). HortScience 31: 460-462

Matsumoto K, Tamura F, Chun J P \& Tanabe K (2006). Native Mediterranean Pyrus rootstock, $P$. amygdaliformis and $P$. elaeagrifolia, present higher tolerance to salinity stress compared with Asian Natives. Journal of the Japanese Society for Horticultural Science 75: 450-457

Monteuuis O (1994). Effect of technique and darkness on the success of meristem micrografting of Picea abies. Silvae Genetica 43: 91-95

Monteuuis O (1996). In vitro shoot apex micrografting of mature Acacia mangium. Agroforestry Systems 34: 231-217

Monteuuis O (2012). In vitro grafting of woody species. Propagation of Ornamental Plants 12: 11-24

Murashige T \& Skoog F (1962). A revised medium for rapid growth and bioassays with tobacco tissue cultures. Physiologia Plantarum 15: 473-497

Murashige T, Bitters W P, Rangan T S, Nauer E M, Roistacher C N \& Holliday B P (1972). A technique of shoot apex grafting and its utilization towards recovering virus free Citrus clones. HortScience 7: 118-119
Musacchi S, Ganino T, Grassi S \& Fabbri A (2004). Grafting in vitro shoots on acclimating plants: morphological and anatomical aspects of compatible and incompatible pear / quince combinations. Acta Horticulturae 658: 559-563

Nas M N \& Read P E (2003). Simultaneous micrografting, rooting and acclimatization of micropropagated American chestnut, grapevine and hybrid hazelnut. European Journal of Horticultural Science 68: 234237

Nava R, Garcia A V, Marin C \& Villegas Z (2011). Clonal propagation of elite Carica papaya L. plants using in vitro and in vivo micrografting. Interciencia 36: $517-$ 523

Navarro L, Roistacher C N \& Murashige T (1975). Improvment of shoot tip grafting in vitro for virus free Citrus. Journal of the American Society for Horticultural Science 100: 471-479

Nunes J C O, Abreu M F, Dantas A C M, Pereira A J \& Pedrotti E L (2005). Morphological characterization in apple micrografts. Revista Brasileira de Fruticultura 27: $80-83$

Obeidy A A \& Smith M A L (1991). A versatile new tactic for fruit tree micrografting. HortTechnology 1: 91-95

Onay A, Pirinc V, Adiyaman F, Isıkalan C, Tilkat E \& Basaran D (2003). In vivo and in vitro micrografting of pistachio, Pistacia vera L. cv. "Siirt". Turkish Journal of Biology 27: 95-100

Onay A, Pirinc V, Yıldırım H \& Basaran D (2004). In vitro micrografting of mature pistachio (Pistacia vera var. Siirt). Plant Cell, Tissue and Organ Culture 77: 215219

Ozden-Tokatlı Y, Akdemir H, Tilkat E \& Onay A (2010). Current status and conservation of Pistacia germplasm. Biotechnology Advances 28: 130-141

Ozzambak E \& Schmidt H (1991). In vitro and in vivo micrografting of cherry (Prunus avium L.). Gartenbauwissenschaft 56: 221-223

Parthasarathy V A, Nagaraju V \& Rahman S A S (1997). In vitro grafting of Citrus reticulata Blanco. Folia Horticulturae 9: 87-90

Sato J E (1967). A modifred method for load staining of thin sections. Journal of Electron Microscopy 16: 133

Sharma S, Singh B, Rani G, Zaidi A A, Halan V K, Nagpal A K \& Virk G S (2008). In vitro production of Indian citrus ringspot virus (ICRSV) free Kinnow plants employing thermotherapy coupled with shoot 
tip grafting. Plant Cell, Tissue and Organ Culture 92: 85-92

Stempak J C \& Ward W P (1964). An improved staining method for electron microscopy. The Journal of Cell Biology 22: 697-701

Thimmappaiah G T, Puthra S \& Anil S R (2002). In vitro grafting of cashew (Anacardium occidentale L.). Scientia Horticulturae 92: 177-182

Toroncoso A, Linan J, Cantos M, Acebedo M M \& Rapoport H F (1999). Feasibility and anatomical development of an in vitro olive cleft-graft. The Journal of Horticultural Science \& Biotechnology 74: 584-587
Volk G M, Bonnart R, Krueger R \& Lee R (2012). Cryopreservation of citrus shoot tips using micrografting for recovery. CryoLetters 33: 418-426

Yildırım H, Onay A \& Suzerer V (2010). Micrografting of almond (Prunus dulcis Mill.) cultivars "Ferragnes" and "Ferraduel". Scientia Horticulturae 125: 361367

Yin H, Yan B, Sun J, Jia P, Zhang Z, Yan X, Chai J, Ren Z, Zheng G \& Liu H 2012. Graft-union development: a delicate process that involves cellcell communication between scion and stock for local auxin accumulation. Journal of Experimental Botany 63: 4219-4232 